\title{
Sustainability of cocoa production in Indonesia
}

\author{
Muhardi $^{1{ }^{1}{ }^{*}, \text { Abdul Rahim }}{ }^{1}$, Effendy ${ }^{2}$, Made Antara ${ }^{2}$, Rustam Abdul Rauf ${ }^{2}$, Arifuddin Lamusa ${ }^{2}$, Christoporus ${ }^{2}$, \\ Hadayani $^{2}$, Dian Safitri ${ }^{2}$, and Jangkung Handoyo Mulyo ${ }^{3}$ \\ ${ }^{1}$ Department of Agrotechnology, Tadulako University, Palu, Indonesia 94118 \\ ${ }^{2}$ Department of Agriculture Economics, Tadulako University, Palu Indonesia 94118 \\ ${ }^{3}$ Department of Agricultural Socio-Economics, Gadjah Mada University, Yogjakarta, Indonesia 55281
}

*Corresponding author: muhardi_hasanuddin@yahoo.com

\section{Abstract}

The objective of this study was to present empirical evidence about the sustainability of cocoa farming in Indonesia and how decisions are made in producing cocoa beans. This study used a survey method involving a questionnaire for collecting data. The results showed that the sustainability of cocoa farming was determined by weak sustainable ecological factors (46.07\%), moderately sustainable socioeconomic factors (54.43\%), moderately sustainable technological factors $(55.95 \%)$, moderately sustainable factors that help farmers in cocoa farming $(59.60 \%)$, and weak sustainable factors in cocoa farming families' futures (47.52\%). To increase the sustainability of cocoa farming, the current study found that farmer education, cocoa crop rejuvenation, cocoa pest and disease control, cleanliness and quality of cocoa beans, cocoa productivity, institutions, extension, technology, credit availability, and stability of cocoa bean prices are the most important factors to be improved.

Keywords: Sustainability, cocoa beans, ecological factors, socioeconomic factors, technological factors.

Abbreviations: CBP_cocoa black pod; $C P B$ _cocoa pod borer; EF_ecological factors; FF_factors of cocoa farming families' future; EIR_eastern Indonesia Region; FH_factors that help farmers in cocoa farming; MDS_multi dimensional scaling; RMS_root mean square; SF_socioeconomic factors; TF_technological factors.

\section{Introduction}

In 2002, cocoa plantations provided employment and source of income for around 900 thousand family heads of farmers, mostly in Eastern Indonesia Region (EIR). They also provided the largest foreign exchange contribution to the three plantation sub-sectors after rubber and palm oil, presenting a value of US \$ 701 million (Ministry of Industry, 2007). Indonesia was the 3rd largest cocoa producing country in the world after Ivory Coast and Ghana (Effendy et al., 2013; Effendy, 2015). However, in 2018, cocoa productivity greatly decreased, causing Indonesia to fall to 5th place after Côte d'Ivoire, Ghana, Ecuador, and Nigeria (Effendy et al., 2019). The decrease in cocoa productivity has been a result of pests and diseases, in combination with the advanced maturity of plants as they have become older (Effendy et al., 2013; Nurhidaya et al., 2015; Effendy, 2015). In addition to decreasing productivity, the quality of cocoa beans was low and farming was inefficient, decreasing cocoa farming income (Effendy and Antara, 2015; Effendy, 2018a).

Presence of disease, pests, low productivity and low cocoa farming income persuade farmers to convert the function of cocoa land to other crops such as coffee and pepper, disrupting the sustainability of cocoa farming in Indonesia.
Applying sustainability in agriculture has gained popularity since the Brundtland report in 1987 (Akcaoz and Kizilay, 2009). Interest in the concept has grown largely because of low agricultural income and pest/disease attacks, leading to large impacts on agricultural output, farmers' welfare, and overall environmental problems (Giannoccaro and Berbel, 2014; Muhardi and Effendy, 2017). This means it is important to determine the extent to which certain farming systems are sustainable or not (Van calker et al., 2005; Akcaoz and Kizilay, 2009). In general, agricultural sustainability concerns economic, social and ecological sustainability (Shearman 1990; Heinen 1994; Hansen 1996). According to Akcaoz and Kizilay (2009), there have been various problems in the economic and social sustainability of cow's milk activities, such as price instability, organizational structure, animal diseases, cleanliness and quality, low productivity, high unit production costs, marketing problems, lack of government support, and low level of education among farmers.

The findings of Adamišin et al. (2017) showed that sustainability of agricultural economic performance is determined by production factors such as labor, capital and natural resources. In addition, agricultural entrepreneurs also 
need subjective assumptions such as imagination, ambition, willingness to bear risks, organizational skills, and better management. This was consistent with the results of the study of Olson et al. (2008), which showed that $87 \%$ of company sustainability depends on the work of senior management and only $13 \%$ depended on external factors. According to Adamišin et al. (2015), effective management of agricultural entities could be a good inspiration for these companies. Validated effective elements in management could be applied to agricultural entities, so that they could contribute to higher economic performance.

In accordance with the attention that is currently being paid to sustainability in agriculture, we became interested in analyzing the sustainability of cocoa farming in Central Sulawesi, Indonesia. The objective of this study was to present empirical evidence on the sustainability of cocoa farming in Indonesia, as well as how decisions were made in the production of cocoa beans.

\section{Results and Discussion}

The results of the analysis using Rapco-Central Sulawesi method (Rapid Appraisal for Cocoa on Central Sulawesi) showed that the sustainability index of ecological factors was $46.07 \%$ (weakly sustainable); socioeconomic factors of farmers was $54.43 \%$ (moderately sustainable), technological factors was $55.95 \%$ (moderately sustainable), factors that help farmers in cocoa farming was $59.60 \%$ (moderately sustainable), and factors of cocoa farming families' future was $47.52 \%$ (weakly sustainable). Each of the factors and attributes are sensitive and require improvement for sustainability. The value of each factor that affected the sustainability of cocoa farming is presented as follows.

\section{Ecological factors}

Ecological factors that affected the sustainability of cocoa farming consists of 10 attributes, namely (1) land suitability and agro-climate for cocoa plants, (2) land and environmental management, (3) use of cacao beans, (4) cocoa productivity, (5) the quality of cocoa beans produced, (6) the use of organic material as fertilizer, (7) the age of the cocoa plant, (8) cocoa pod borer (CPB) pest attack, (9) attack of cocoa black pod (CBP) disease, (10) attack of pests and diseases other than CPB and CBP. We analyzed these attributes using the Rapco-Central Sulawesi method.

The analysis results of the Rapco-Central Sulawesi method show that the effect of ecological factors on the sustainability of cocoa farming (MDS sustainability index) was $46.07 \%$ (weakly sustainable) with stress value $=0.137$ and $R^{2}=0.944$. Stress value $0.137<0.25$ and the value of $R^{2}=0.944$ shows that the model using these attributes explained $94.40 \%$ of the existing models. The Monte Carlo sustainability index was $45.54 \%$, when compared to MDS. There was a difference of $0.53 \%$, which is certainly smaller than 1.0 , showing that the model was in a condition of the goodness of fit (Kavanagh and Pitcher, 2004).

Leverage analysis results show that the ecological factors that became the main levers in the sustainability of cocoa farming were (1) the age of cocoa plants, (2) the use of organic materials, (3) CPB attack, and (4) land and environmental management (Fig 1). Increasing the sustainability status of cocoa farming in the future relies on addressing these attributes.

The age of the cocoa plant was the most sensitive attribute. The results of the field survey show that the age of cocoa plants ranged from 7 to 29 years, averaging 18 years. Cocoa plants that were old have started to decrease in productivity (Gugere et al., 2016), while at the same time pests and diseases more easily attacked them. Cocoa yield productivity also tended to decrease as farmers were less optimal in cocoa land and environment management, including pruning, fertilizing, eradicating pests and diseases. Pests and diseases that predominantly attacked cocoa were CPB and CBP. Organic fertilizer uses also require consideration because it could affect the production and quality of cocoa beans (Effendy and Antara, 2015; Effendy et al., 2019). Cocoa productivity ranged from 250 to $1375 \mathrm{~kg} / \mathrm{ha} /$ year dry beans with an average of 706 $\mathrm{kg} / \mathrm{ha} /$ year. Genetically, cocoa production has the potential to reach 1800 to $2750 \mathrm{~kg} / \mathrm{ha}$ (DPDJP., 2009). To increase the productivity and sustainability index of cocoa farming, ecological factors need to be addressed, including rejuvenating cocoa plants, controlling pests and diseases more intensively, use of organic fertilizers, land and the environment management, and using superior seeds resistant to pests and diseases that also have high productivity.

\section{Socioeconomic factors}

Socioeconomic factors affecting cocoa farming sustainability consist of 12 attributes, namely (1) level of formal education of farmers, (2) scale of cocoa farming, (3) cocoa farming experience, (4) family participation in cocoa farming, (5) level of labor absorption from cocoa farming, (6) cocoa farming income, (7) farming income other than cocoa, (8) income outside agriculture, (9) market access, (10) dependence on foreign market prices, (11) the size of farmer households, and finally (12) the age of the cocoa farming manager. We analyzed these attributes using the Rapco-Central Sulawesi method.

The analysis results of the Rapco-Central Sulawesi show that the effect of socioeconomic factors on the sustainability of cocoa farming (MDS sustainability index) was $54.43 \%$ (moderately sustainable) with stress value $=0.149$ and $\mathrm{R}^{2}=$ 0.921 . Stress value $0.149<0.25$ and the value of $R^{2}=0.921$ shows that the model using these attributes explained $92.21 \%$ of the existing models. The Monte Carlo sustainability index was $54.431 \%$, when compared to MDS. There was a difference of $0.001 \%$ and this was smaller than 1.0 , indicating that the model was in a condition of the goodness of fit (Kavanagh and Pitcher, 2004).

Leverage analysis results showed that the socioeconomic factors that were primary levers in the sustainability of cocoa farming were (1) dependence on foreign market prices, (2) cocoa farming income, (3) family participation in cocoa farming, and (4) farming income other than cocoa, (Fig 2). Focusing on these attributes could allow the region to improve the sustainability status of cocoa farming going forward.

Based on the analysis results, community cocoa farming in Central Sulawesi was quite profitable. Unfortunately, competitiveness of cocoa from this region was low because it was not supported by the quality of the results due to less optimal cultivation and postharvest treatments (Effendy, 
2018a). Therefore, cultivation and postharvest technologies require improvement to increase productivity and quality of cocoa yields (Effendy et al., 2019). The price of cocoa beans in Indonesia relies on the world cocoa market price. Quality cocoa beans gain higher prices. Therefore, to increase the index and sustainability status of cocoa farming, it is also necessary to improve these sensitive attributes through implementing better cocoa cultivation technology, postharvest, and marketing access.

\section{Technological factors}

The current study found that technological factors affecting the sustainability of cocoa farming were six-fold: (1) knowledge of cocoa cultivation, (2) level of technological mastery, (3) cacao crop pruning action, (4) fertilizing action, (5) cocoa pest and disease control action, (6) availability of the result processing industry. We analyzed these attributes through the Rapco-Central Sulawesi method.

The results of the Rapco-Central Sulawesi analysis showed the effect of technological factors on the sustainability of cocoa farming (sustainability index) was $55.95 \%$ (moderately sustainable) with stress value $=0.163$ and $R^{2}=0.910$. Stress value $0.163<0.25$ and the value of $R^{2}=0.910$ shows that the model using these attributes explained $91.00 \%$ of the existing model. The Monte Carlo sustainability index was $56.70 \%$, when compared to MDS. There was a difference of $0.75 \%$ and this was smaller than 1.0, showing the model was in a condition of the goodness of fit (Kavanagh and Pitcher, 2004).

Leverage analysis showed that the technological factors that became the main levers in the sustainability of cocoa farming were (1) pest and disease control action, (2) level of technological mastery, (3) knowledge of cocoa cultivation, and (4) availability of the result processing industry (Fig 3). Observing and acting to optimize such attributes would increase the sustainability status of cocoa farming in the future.

The level of technological mastery remains relatively low, largely owing to the level of education of farmers, who on average, have attained only junior high school or lower. This makes it difficult for farmers to receive or seek information on cocoa farming technology. Poor technological mastery has caused farmers to be unable to combat attacks of pests and diseases on their cocoa plants, leading to low productivity. Therefore, to increase the index and sustainability status of cocoa farming, it is necessary to improve these sensitive attributes (among others) by means of more intensive agricultural extension and training. Likewise, it is necessary to improve the frequency, content, and quality of extension program (Effendy et al., 2013; Effendy et al., 2019).

\section{Factors that help farmers in cocoa farming}

There are 6 factors assisting farmers in cocoa farming and thereby affecting its sustainability: (1) the extension program, (2) loans when needed, (3) government support, (4) participation in farmer cooperatives, (5) suppliers of agricultural inputs, and (6) farmer groups. We used the RapcoCentral Sulawesi method to analyze these attributes.

The analysis results of the Rapco-Central Sulawesi method show the factors that help farmers for sustainability of cocoa farming (sustainability index) by $59.60 \%$ (moderately sustainable) with stress value $=0.167$ and $R^{2}=0.9096$. Stress value $0.167<0.25$ and the value of $R^{2}=0.9096$ shows that the model using these attributes explained $90.96 \%$ of existing models. The Monte Carlo sustainability index was $60.30 \%$, when compared to MDS. There was a difference of $0.70 \%$ and this was smaller than 1.0, showing the model is in a condition of the goodness of fit (Kavanagh and Pitcher, 2004).

The leverage analysis results show that the main levers in cocoa farming sustainability were (1) could get a loan when needed, (2) farmer groups, (3) government support, and (4) extension programs (Fig 4). Addressing these 6 attributes could increase the sustainability status of cocoa farming.

Farmer groups in Central Sulawesi are better developed, but not optimally, leading to their inability to help their members in terms of the availability of agricultural inputs. According to farmers, the availability of agricultural inputs was very important in cocoa farming. Agricultural inputs, such as fertilizer, greatly affect cocoa production (Effendy, 2018b). In farmer groups, cooperation between members could encourage more efficient use of resources. Farming efficiency could reduce production costs and thereby increase profit margins (Effendy et al., 2019). Farmer groups could also be a means of technological innovation diffusion and knowledge (Stockbridge et al., 2003; Nuryanti and Swastika, 2011).

Farmers showed themselves to be in sore need of financial institutions such as banks and cooperatives. The results of interviews with farmers indicated that they had difficulty acquiring financial loans, which forms a significant barrier to preparing production inputs. Government support was highly expected in the availability of facilities and infrastructure in rural areas so that farmers could meet their needs.

\section{Factors affecting future of cocoa farming families}

Factors affecting future of cocoa farming families and sustainability of cocoa farming consist of 8 attributes, namely (1) agricultural education programs for young people, (2) availability of home credit services, (3) increases in educational opportunities, (4) improvement of infrastructure (roads, telecommunications, etc.), (5) increasing the availability of employment outside agriculture, (6) providing support in the event of a natural disaster (earthquakes, floods, landslides, etc.), (7) guaranteeing cocoa beans prices, (8) increases in credit availability. We used the Rapco-Central Sulawesi method to analyze these attributes.

The analysis using Rapco-Central Sulawesi method show factors that affect the future of cocoa farming families and sustainability of cocoa farming (sustainability index) was $47.52 \%$ (weakly sustainable) with stress value $=0.178$ and $R^{2}=$ 0.8791 . Stress value $0.178<0.25$ and the value of $R^{2}=0.8791$ shows that the model using these attributes explained $87.91 \%$ of the existing models. The Monte Carlo sustainability index was $47.58 \%$, and when compared to MDS there was a difference of $0.059 \%$, smaller than 1.0 . This shows that the model is in a condition of goodness of fit (Kavanagh and Pitcher, 2004).

Leverage analysis results show that the main levers in the sustainability of cocoa farming were (1) increasing credit availability, (2) guaranteeing cocoa beans, (3) providing support in the event of natural disasters (earthquakes, floods, 
Table 1. Factors and attributes that tended to affect the sustainability of cocoa farming.

\begin{tabular}{|c|c|c|}
\hline Factors & Attributes & Symbol \\
\hline \multirow[t]{10}{*}{ Ecological factors } & (1) land suitability and agro-climate & EF1 \\
\hline & (2) land and environmental management & $\mathrm{EF} 2$ \\
\hline & (3) use of cacao beans & $\mathrm{EF} 3$ \\
\hline & (4) cocoa productivity & EF4 \\
\hline & (5) the quality of cocoa beans produced & EF5 \\
\hline & (6) the use of organic material as fertilizer & EF6 \\
\hline & (7) the age of the cocoa plant & EF7 \\
\hline & (8) cocoa pod borer (CPB) pest attack & EF8 \\
\hline & (9) attack of cocoa black pod (CBP) disease & EF9 \\
\hline & (10) attack of pests and diseases other than CPB and CBP & EF10 \\
\hline \multirow[t]{12}{*}{ Socioeconomic Factors } & (1) formal education of farmers & SF1 \\
\hline & (2) scale of cocoa farming & SF2 \\
\hline & (3) cocoa farming experience & SF3 \\
\hline & (4) family participation in cocoa farming & SF4 \\
\hline & (5) labor absorption from cocoa farming & SF5 \\
\hline & (6) cocoa farming income & SF6 \\
\hline & (7) farming income other than cocoa & SF7 \\
\hline & (8) income outside agriculture & SF8 \\
\hline & (9) market access & SF9 \\
\hline & (10) dependence on foreign market prices & SF10 \\
\hline & (11) the size of farmer households & SF11 \\
\hline & (12) the age of the cocoa farming manager & SF12 \\
\hline \multirow[t]{6}{*}{ Technological factors } & (1) knowledge of cocoa cultivation & TF1 \\
\hline & (2) level of technological mastery & TF2 \\
\hline & (3) cacao crop pruning action & TF3 \\
\hline & (4) fertilizing action & TF4 \\
\hline & (5) cocoa pest and disease control action & TF5 \\
\hline & (6) availability of the result processing industry & TF6 \\
\hline \multirow{6}{*}{$\begin{array}{llr}\text { Factors } & \text { that help } \\
\text { farmers in } & \text { cocoa } \\
\text { farming } & & \end{array}$} & (1) extension program & $\mathrm{FH} 1$ \\
\hline & (2) could get a loan when needed & $\mathrm{FH} 2$ \\
\hline & (3) government support & $\mathrm{FH} 3$ \\
\hline & (4) participation in farmer cooperatives & $\mathrm{FH} 4$ \\
\hline & (5) suppliers of agricultural inputs & FH5 \\
\hline & (6) farmer groups & $\mathrm{FH} 6$ \\
\hline \multirow{8}{*}{$\begin{array}{l}\text { Factors of cocoa farming } \\
\text { families' future }\end{array}$} & (1) agricultural education program for young people & FF1 \\
\hline & (2) availability of home credit services & FF2 \\
\hline & (3) increase educational opportunities & FF3 \\
\hline & (4) increasing infrastructure & FF4 \\
\hline & (5) availability of employment outside agriculture & FF5 \\
\hline & (6) providing support in the event of a natural disaster & FF6 \\
\hline & (7) give guarantees the of cocoa beans price & FF7 \\
\hline & (8) increase in credit availability & FF8 \\
\hline
\end{tabular}

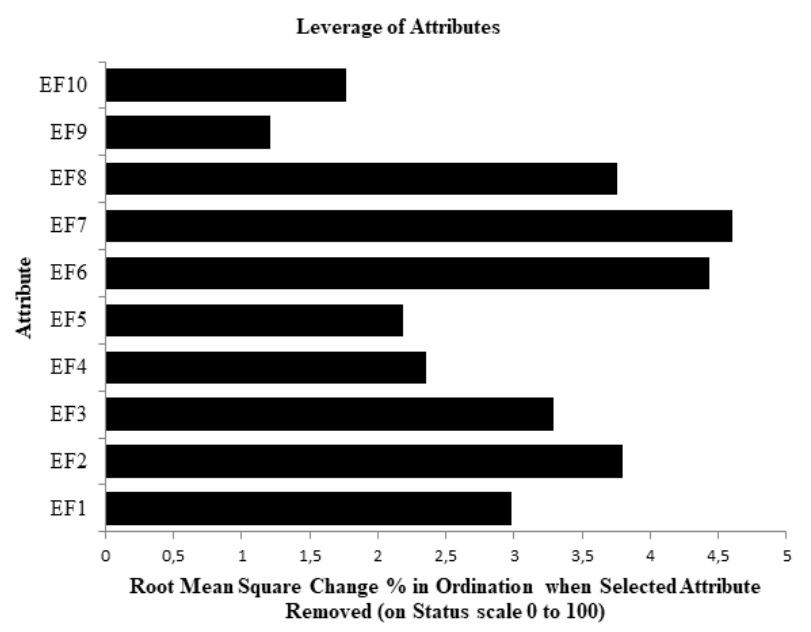

Fig 1. Leverage (sensitivity) analysis results of ecological factors. 


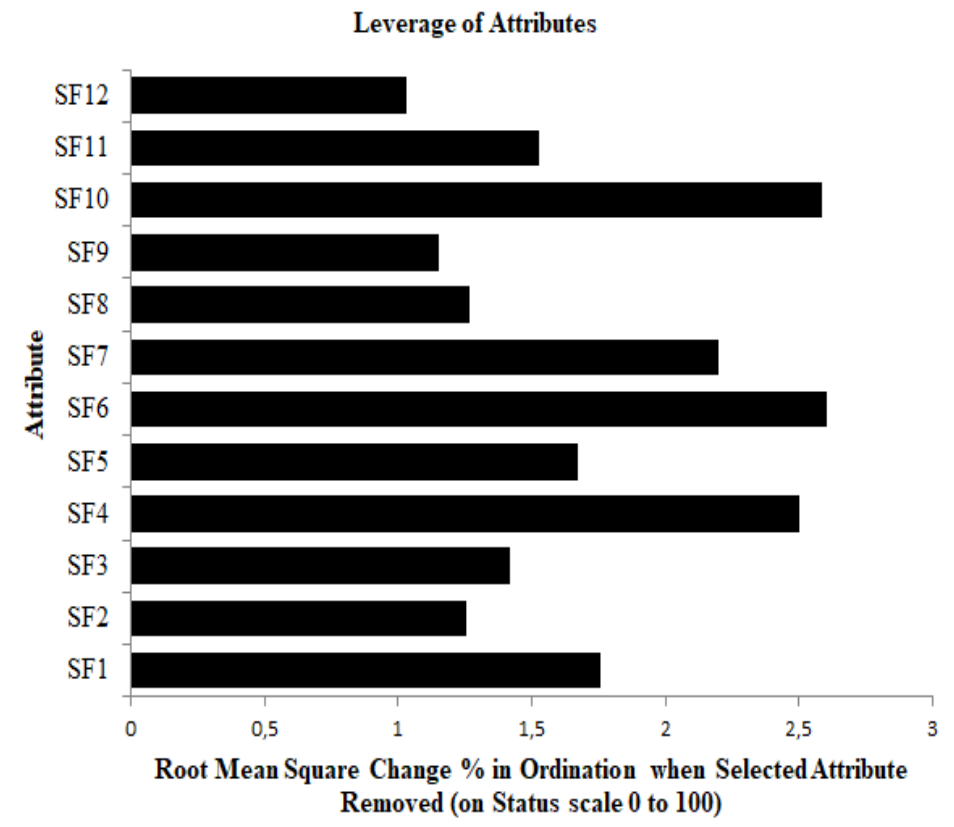

Fig 2. Leverage (sensitivity) analysis results of socioeconomic factors.

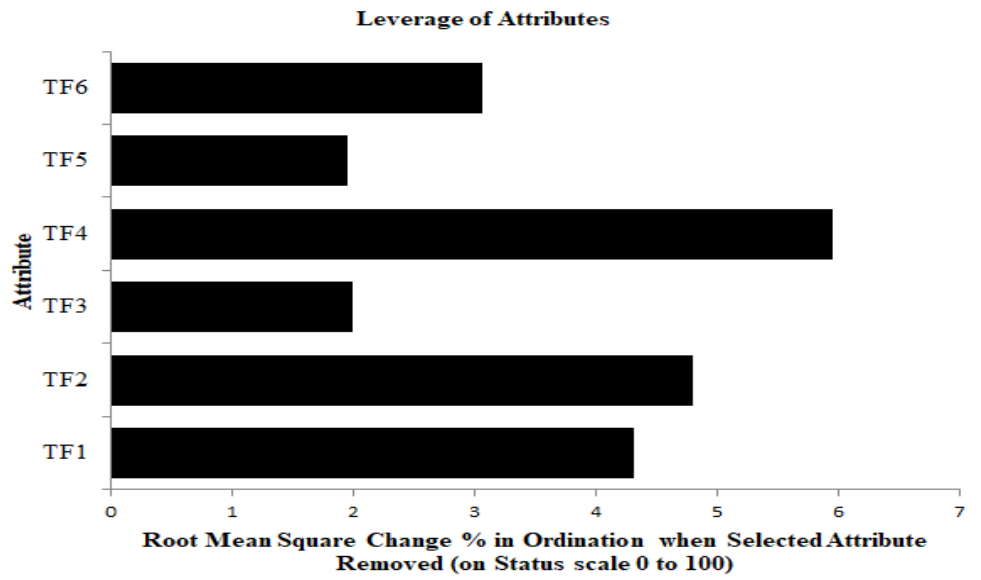

Fig 3. Leverage (sensitivity) analysis results of technological factors.

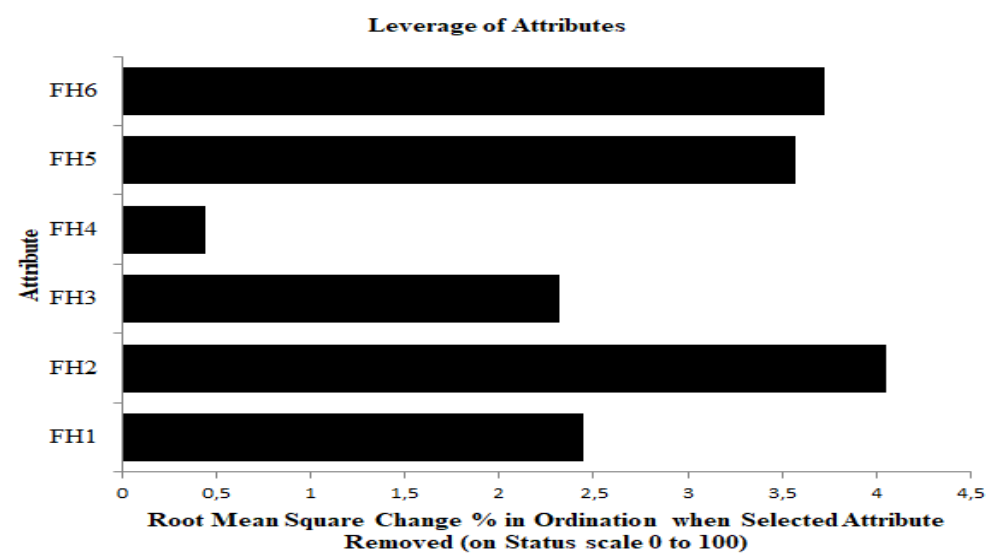

Fig 4. Leverage (sensitivity) analysis results of factors that help farmers. 
Leverage of Attributes

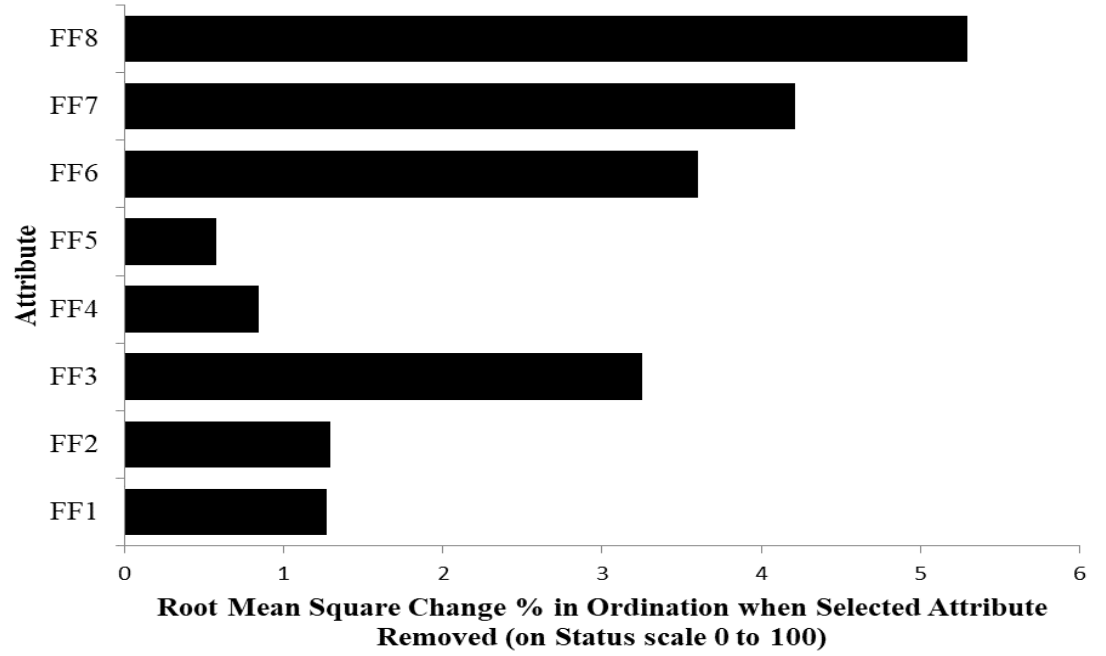

Fig 5. Leverage (sensitivity) analysis results of factors of cocoa farming families' futures.

landslides, etc.), and (4) increasing educational opportunities (Fig 5). Increasing the sustainability status of cocoa farming in the future may rely on consulting these attributes. Financial institutions such as banks were already available in Central Sulawesi, but the availability of credit services for farmers in rural areas remains poor. This means that such institutions are still unable to help farmer families in terms of the finance. According to farmers, the availability of credit services is very important for home loans and the availability of agricultural inputs. In addition, credit services are useful for increasing opportunities for higher education among farmer's children. Education helps farmers make the right decisions in farming, including using resources more efficiently and implementing more effective methods (Singha et al., 2012; Abdullah and Samah, 2013).

Government support in the event of a natural disaster greatly helps farmers to continue productivity. Interviews with farmers revealed that they were greatly helped by government assistance in improving infrastructure, such as roads and telecommunications, especially with reference to the natural disaster on September 28, 2018 in Palu. Besides that, they also look forward to government assistance in stabilizing cocoa prices.

\section{Materials and Methods}

\section{Research areas}

The current study conducted a cocoa farming sustainability survey in Central Sulawesi Province, Indonesia. Primary data collection used a questionnaire with a Likert scale starting from 0 (very low) to 5 (very high). Sampling used a simple random method. The sample entailed 320 cocoa farmers. The study occurred from March to May 2019, with sampling carried out randomly in the villages of Berdikari and Rahmat (represented Sigi District), while the villages of Sidole and Tanampedagi represented the Parigi Moutong District.

\section{Analysis method}

The analytical method involved Multi-Dimensional Scaling (MDS) called Rapfish. We modified this method into the Rapid Appraisal for Cocoa on Central Sulawesi, expressing results in the form of an index and sustainability status. The results to obtain from the application of this method were attributes that were sensitive to the index and the sustainability status of cocoa farming. Table 1 exhibits the factors and attributes analyzed in the sustainability of cocoa farming.

The index categories and the sustainability status of cocoa farming studied have an interval of 0 to 100 percent as follows. 0.00 - 25 bad category (non-sustainable)

25.01 - 50.00 weakly category (weakly sustainable)

50.01 - 75.00 moderately category (moderately sustainable)

75.01 - 100 good category (sustainable)

Leverage analysis, Monte Carlo analysis, Stress value determination and coefficient of determination $\left(R^{2}\right)$ were also done in MDS analysis. Leverage analysis (sensitivity analysis) was done to find out which attributes were considered to have a strong effect on improving the sustainability status of cocoa farming. Attributes that have a strong effect were seen in the change of Root Mean Square (RMS) ordinance on the X-axis. The greater the change in RMS, the more sensitive the role of these attributes to the improvement of sustainability status. Monte Carlo analysis was used to assess the MDS output if the difference between the Monte Carlo index and MDS was less than 1 showing that the cocoa farming sustainability index status value corresponded to a 95 percent confidence interval. Stress value and coefficient of determination $\left(R^{2}\right)$ functioned to know the suitability of the MDS model if the stress value was smaller than 0.25 and the coefficient of determination $\left(R^{2}\right)$ closed to 1 showed the goodness of fit (Kavanagh and Pitcher, 2004). 


\section{Conclusion}

This study has identified several problems in the sustainability of cocoa farming such as farmers' education remaining low, the old age of cocoa plants, cocoa pests and diseases, cleanliness and quality of cocoa beans, low productivity, institutions, extension, technology, production costs, credit availability, and price instability of cocoa beans. The research findings support this argument, namely (a) weakly sustainable ecological factors $(46,07 \%)$, (b) moderately sustainable socioeconomic factors $(54,43 \%)$, (c) moderately sustainable technological factors $(55,95 \%)$, (d) factors that help farmers in cocoa farming which were moderately sustainable $(59,60 \%)$, and finally (e) weakly sustainable factors of cocoa farming families' futures $(47,52 \%)$.

\section{Acknowledgements}

We would like to thank the Ministry of Research, Technology and Higher Education of the Republic of Indonesia for providing this study's funding through DRPM under the contract number: 351.b.m / UN28.2 / PL / 2019.

\section{References}

Abdullah FA, Samah BA (2013) Factors Impinging Farmers' Use of Agriculture Technology. Asi Soc Sci. 9(3): 120-124.

Adamišin P, Kotulič R, Kravčáková Vozárová I, Vavrek R (2015) Natural climatic conditions as a determinant of productivity and economic efficiency of agricultural entities. Agric. Econ. - Czech, 61: 265-274.

Adamisin P, Kotulic R, Vozarova IK 2017 Legal form of agricultural entities as a factor in ensuring the sustainability of the economic performance of agriculture. Agric. Econ. - Czech, 63, 2017 (2): 80-92

Akcaoz H, Kizilay H (2009) Sustainability of dairyproduction in Turkey: A case study. Agric Econ -Czech. 55(1): 25-32.

DPDJP (2009) Handbook of cultivation technical of cocoa (Theobroma cacao L.). The Increasing Production Movement and National Cocoa Quality, Jakarta (In Indonesia).

Effendy, Antara M (2015) Effect of input production against quality of cocoa beans. Am J of App. Sci. 12(10): 709-713.

Effendy, Hanani N, Setiawan B, Muhaimin AW (2013) Effect characteristics of farmers on the level of technology adoption side-grafting in cocoa farming at Sigi RegencyIndonesia. J of Agri Sci. 5(12): 72-77.

Effendy, Pratama MF, Rauf RA, Antara M, Basir-Cyio M, Mahfudz et al (2019) Factors influencing the efficiency of cocoa farms: A study to increase income in rural Indonesia. PLoS ONE. 14(4): e0214569.

Effendy (2015) Increasing of cocoa farmers household income with two stage least squares method. Mod App Sci. 9(6): $120-127$.
Effendy (2018a) Factors affecting variation of total factor productivity in cocoa farming in the Central Sulawesi, Indonesia. AJCS. 12(04): 655-660.

Effendy (2018b) Changes of technical efficiency and total factor productivity of cocoa farming in Indonesia. Bul J of Agric Sci. 24(4): 566-573.

Giannoccaro G, Berbel J (2014) Farmers' stated responses towards the chemicals use under the CAP liberalization. Agric. Econ.- Czech. 60(1): 9-20.

Gugere JK, Antara M, Alam MN (2016) Production and IncomeAnalysis of Cocoa Farmingin Tongoa Village, Palolo Sub District, Sigi Regency. J. Agroland 23(1): 1-10.

Hansen JW (1996). is agricultural sustainability a useful concept? Agric Syst. 50: 117- 143.

Heinen JT (1994) Emerging, diverging and converging paradigms on sustainable development. Inter J of Sust Develop and World Eco. 1: 22-33.

Kavanagh P, Pitcher TJ (2004) Implementing Microsoft Excel Sofware for Fish: A Technique for The Rapid Appraisal of Fisheries Status. University of British Columbia. Fisheries Centre Research Report 12 (2).

Ministry of Industry (2007) Overview of the Cocoa Industry (in Indonesia).

https://www.google.co.id/?gws rd=ssl\#q=Asosiasi+Kakao+ Indonesia+(2005).+Prospek+Agroindustri+Kakao+Indonesia +di+Pasaran+Dunia+Sampai+Dengan+2010. Accessed 23.7.2019.

Muhardi, Effendy (2017) Cocoa farming patterns for sustainability of Indonesia Lore Lindu National Park (LLNP). AJCS. 11(08), 917-924.

Nurhidaya, Antara M, Effendy (2015) Effect of production input to the quality of cocoa beans and income cocoa farming in palolo sub district sigi district. J. Agroland 22(3): $254-264$.

Nuryanti S, Swastika DKS (2011) Roles of Farmers' Groups in Agricultural Technology Adoption. Forum Penelitian Agro Eko. 29(2): $115-128$.

Olson MS, Van Bever D, Verry S (2008) When growth stalls. Harvard Business Review, 86: 51-62.

Shearman R (1990) The Meaning and Ethics of Sustainability. Envi Manag. 14(1): 1-8.

Singha AK, Baruah MJ, Bordoloi R, Dutta P, Saikia US (2012) Analysis on Influencing Factors of Technology Adoption of Different Land Based Enterprises of Farmers under Diversified Farming System. J of Agric Sci. 4(2): 139-146.

Stockbridge M, Andrew D, Jonathan K, Jamie M, Nigel P (2003) Farmer Organizations For Market Access: An International Review. https://assets.publishing.service.gov.uk/media/57a08cb14 Of0b6497400138e/R8275_040518_IntIRev_FO_MktAccss.p df. Accessed 23.7.2019.

Van-Calker KJ, Berentsen PBM, Giesen GWJ, Huirne RBM (2005) Identifying and ranking attributes that determine sustainability in Dutch dairy farming. Agric and hum Val. 22(1): 53-63. 